\title{
Glossary of technical terms and abbreviations
}

abnormal return A return on an asset above what would be expected given its riskiness.

ABS Asset-backed security. This is a tradable instrument backed by a pool of loans.

ADR American depository receipt. This confers ownership rights to UK shares and is traded in its own right. It avoids the need to register change in share ownership and transactions do not involve stamp duty.

adverse selection A problem created by asymmetric information in a financial transaction: the people who are most undesirable from the other party's point of view are the ones who are most likely to want to engage in the transaction.

AIF Authorised investment fund. This is a fund authorised by the FSA or, after 2013, by the FCA.

AIM Alternative Investment Market. This market in London for the shares of smaller companies, opened in June 1995.

American option An option that can be exercised any time before the expiry date.

annuity An investment that pays fixed sums of money over a period of time. arbitrage Buying and selling securities in such a way that profits are made from the price differences without incurring risk.

ask price The price at which a market maker is prepared to sell a security. asymmetric information The situation where one party to a transaction has more information relating to that transaction than the other party. ATM Automated teller machine.

backwardation A market for a commodity is said to be in backwardation when the prices for delivery in the future (i.e. the futures price) are less than the current price, sometimes referred to as normal backwardation. BACS Bankers' Automated Clearing Services.

bail-in An arrangement whereby holders of unsecured debt and preference shares would be forced to convert their holdings into equity when the regulatory authorities so decide. 
Bank of England The central bank of the UK.

bank rate An old term reincarnated to define the short-term interest rate set by the MPC (q.v.).

banker's acceptance A bill of exchange (q.v.) endorsed by a bank (i.e. the bank is guaranteeing the bill). It commands a low rate of discount.

Basel accords Three international agreements detailing the arrangements for the prudential control of banks.

basis The spread or difference between two rates, such as the difference between the futures price and that of the underlying cash instrument. basis point One hundredth of $1 \%$.

$\mathrm{BCCl}$ Bank of Credit and Commerce International.

bear An operative in a market who believes the price of an asset will fall. bearer bond A bond (q.v.) that is owned by whoever holds it. No registration of ownership is involved.

bid-ask spread The gap between the higher ask price and the lower bid price.

bid rate The price at which a market maker is prepared to buy a security. bill of exchange An order in writing telling a person to pay a certain sum of money to another at a specific time in the future. Bills are mainly used in foreign trade. The person who promises to pay is said to accept the bill. A prime bank bill is a bill accepted by a high-class bank. A fine trade bill is a bill accepted by a trader with a first-class reputation. A bill bears no interest rate and is said to be discounted when it is sold for a price less than its maturity value.

BIS Bank for International Settlements. This is a central bank to the national central banks. It is concerned with banking issues and, in particular, stability of the banking system.

bond Title issued by the public sector or a company acknowledging the existence of debt. Normally a bond commands a fixed rate of interest based on its nominal value.

broker A person who arranges deals between buyers and sellers on behalf of a third party. A broker is not trading on her or his own account but earns a commission on the deal called a brokerage fee.

bull An operative in a market who believes the price of an asset will rise. butterfly spread An option trading strategy that mimics a straddle (q.v.) but with a floor being provided for the maximum loss or a ceiling to the maximum gain.

calendar spread An option trading strategy involving the buying and selling of call (put) options with different maturities.

call option An option that gives the right to buy the underlying security at an agreed price.

CAMELS A framework for testing the soundness of a bank. The letters stand for Capital adequacy, Asset quality, Management, Earnings, Liquidity and Sensitivity to market risk. 
cap A derivative instrument designed to fix a maximum level to which a price or interest rate can rise.

СВОТ Chicago Board of Trade.

CCP Central counter-party. Such parties interpose themselves between the buyer and seller of the security. Thus CCPs act as a buyer to each seller and a seller to each buyer and become the counter-party in all the trades they clear.

CD Certificate of deposit. This is a negotiable instrument issued by a bank or building society acknowledging an interest-bearing time deposit.

CDS Credit default swap. A credit derivative that provides insurance to the buyer against default on loans.

CET1 Common equity tier 1 capital, broadly defined as ordinary shares plus retained profits.

CGNCR Central government net cash requirement. This is the amount of money the government has raise to finance the surplus of expenditure over revenue.

CHAPS Clearing House Automated Payments System. This is an automated end-of-day net settlement system for sterling wholesale payments.

clean price The price of a bond that excludes the accrued interest since the last coupon payment.

CME Chicago Mercantile Exchange.

CoCo A contingent convertible bond that is transformed into equity if a specific event occurs.

collar A derivative instrument designed to fix both a maximum and a minimum level at which a price or interest rate can rise or fall.

collateral Security given for the repayment of a loan.

commercial paper An unsecured promissory note issued by commercial firms promising to pay a fixed sum of money, normally with a maturity of less than 270 days. This security is usually sold at a discount, that is, for less than its nominal or face value.

consortium bank A subsidiary set up by a number of banks for the purpose of making a large loan(s).

contango A market is in contango when the current price of a commodity is lower than the price for delivery in the future (i.e. the futures price). contingent liability Debt that comes into existence on the occurrence of some contingency.

contingent term repo facility A method of providing liquidity to the banks by the Bank of England that can be introduced at times of systemic stress.

convertible bond A bond that can be converted into equity.

coupon Fixed rate of interest payable on a bond.

covered bond A bond backed by a separate group of loans to the public sector or mortgage loans. 
covered interest arbitrage Investing in a security denominated in a foreign currency and covering against the exchange rate risk by taking out an offsetting forward transaction.

credit rating agency A company that assesses the credit worthiness of issuers of debt and other securities.

CSD Central security depository. This is an organisation that holds securities, enabling their transfer between parties, so CSDs are the main operators of the settlement system.

debenture In the UK, a bond that is secured against a firm's assets.

debt rescheduling Formal rearrangement of both debt service payments and repayment of the principal with new maturities.

default Failure of a borrower to make a payment of either interest or principal on the due date.

derivative An instrument whose price is derived from an underlying financial security.

dirty price The price of a bond that includes the accrued interest since the last coupon payment.

discount The payment of an immediate sum in settlement of a larger sum due at a later date.

disintermediation The process of companies/individuals raising finance without a bank or other financial institution acting as an intermediary. dividend Income return on ordinary shares.

DMO Debt Management Office. This is the UK institution responsible for managing government debt.

DTB Deutsche Terminbörse.

duration The average time to maturity of the streams of income from a security, taking into consideration of the timing and size of the cash flow.

DWF Discount window facility. This is available on a continuous basis and permits the banks to swap (exchange) illiquid assets for more liquid government securities. The aim of the scheme is to provide liquidity insurance for the banks.

EBA Euopean Banking Authority. See ESFS for further details.

ECB European Central Bank.

ECP Eurocommercial paper.

EIOPA European Insurance and Occupational Pensions Authority. See ESFS for further details.

EMH Efficient markets hypothesis. This puts forward the view that market prices reflect all available information.

EMIR European Market Infrastructure Regulation.

EMTN Euro-medium-term note.

equity The part of the total capital of a company that belongs to the shareholders. In terms of a company's balance sheet it is the residual after deducting liabilities except those due to shareholders from total assets.

ES Expected shortfall, the average of all losses greater than a cut-off 
point (normally the VaR threshold). It is an alternative measure of the riskiness of a portfolio of assets.

ESFS European System of Financial Supervisors. This is an EU supervisory body set up in 2011. It consists of three supervisory boards: the European Banking Authority (EBA); the European Insurance and Occupational Pensions Authority (EIOPA); and the European Securities and Markets Authority (ESMA). They are responsible for detailed rule setting, policy coordination and coordination of supervision of the individual firms within their respective industries.

ESMA European Securities and Markets Authority. See ESFS for further details.

ESRB European Systemic Risk Board. This is an advisory body with responsibility for the prediction of and monitoring of risk.

ETF Exchange-traded fund. This is an investment fund whose aim is to reproduce the performance of a particular index (e.g. the FTSE 100).

euro The single currency for those members of the EU that have participated in stage 3 of economic and monetary union. It came into existence in January 1999.

eurobank A financial institution that accepts deposits and makes loans in currencies other than that of the country in which it is located (i.e. the 'host country').

eurobond Abond issued in a currency other than that of the country where it is issued (e.g. a bond denominated in dollars issued in London).

eurodollar Dollar deposits held at banks located outside the US. More broadly the term can be used for a deposit denominated in any currency other than that of the host country.

euro-equity Equity issued outside the domestic country of the issuer. euronote Short-term note or debt issued in the syndicated loan market. Short term usually refers to one-, three- or six-month maturities.

European option An option that can be exercised only on the maturity date. European System of Central Banks The central banks of Europe all acting independently of domestic governments under an agreement on monetary union.

exercise price The specified price at which options can be taken up or exercised.

exotic option An option with a non-standard or more complicated payoff.

expected shortfall An alternative method to value at risk (VaR) for measuring the risk on a portfolio.

factoring The act of a financial institution taking over the debts owed to a firm. The price paid for the debts would be less than the nominal amount outstanding (i.e. the debts are discounted and the rate of discount will reflect the relevant interest charge and an allowance for the riskiness of the debt). 
FCA Financial Conduct Authority. This is the body responsible for the protection of consumers.

Federal Reserve Bank The central bank of the US. It is composed of 12 regional reserve banks.

financial future A standardised contract providing for the purchase or sale of a fixed quantity of a financial commodity such as foreign exchange or a bank deposit. The underlying financial instrument is known as the cash instrument.

floating rate An interest rate that is reset at regular intervals, the adjustment usually being made with reference to a key rate such as LIBOR (q.v.).

floor A derivative instrument designed to fix a level below which a price or interest rate cannot fall.

foreign bond A bond issued by a borrower in the capital market of another country but in the domestic currency of that country.

forex Foreign exchange.

forfaiting Buying a client's debts without the right to reclaim in the event of a default (q.v.).

forward contract A contract specifying a price for the delivery of a commodity or financial instrument at an agreed date in the future. This contract differs from a futures contract since the contract is not standardised and can be adjusted according to the needs of the purchaser.

forward premium The gap between the forward exchange rate and the ruling spot rate. If the forward rate is less than the current spot rate then the currency is at a discount. The premium/discount can be expressed as an annual percentage or in the form of cents, say, per $£ 1$.

FPC Financial Policy Committee. This committee of the Bank of England, established in 2013, is responsible for overseeing the stability of the financial system.

FRA Forward rate agreement. This is an agreement in which two parties agree on the level of an interest rate to be paid on a notional deposit for a specific maturity at some specified time in the future.

Fraud Compensation Fund A fund set up to provide compensation to failed pension schemes where the scheme has failed due to the dishonesty of the employer.

FRN Floating-rate note. This is a note issued with provision for revision of the rate of interest at periodic intervals (normally three or six months) in line with a key market rate such as LIBOR (q.v.).

FSA Financial Services Authority. This was the body that, until 2013, was responsible for prudential control of the whole of the UK financial services industry, including the banks.

FSAP Financial Services Action Plan (EU).

FSB Financial Stability Board. This international body was set up to promote financial stability. It consists of central bankers, regulators 
and finance ministers from 24 countries plus representatives of the European Union, the International Monetary Fund and the World Bank. It is part of the BIS (q.v.). It is a consensual body and has no powers to enforce its proposals.

FTSE 100 Financial Times Stock Exchange Index of the 100 leading shares, in terms of market value, traded on the London Stock Exchange. GDP Gross domestic product.

gearing The ratio of debt to equity for a company. It is an alternative term for leverage (q.v.).

GEMM Gilt-edged market maker. This is an institution that 'makes' the market in gilt-edged securities.

gilt-edged security A bond issued by the UK government.

hedge The reduction of risk on exposure to changes in market prices/ rates through taking an offsetting position.

hedge fund An investment fund that is drawn up in such a manner as to avoid the main investment protection legislation. It is usually highly leveraged.

HFT High-frequency trading. This relies on computerised models and trading is directed by an algorithm - a set of rules defining a sequence of operations. Trades are executed in microseconds (millionths of a second).

ICE Intercontinental Exchange. This is a network of exchanges and clearing houses for financial and commodity markets.

IDB Inter-dealer broker.

ILR Indexed long-term repo. This is a bid that will be denominated in terms of the spread over bank rate, hence the term ILR.

IMF International Monetary Fund. This is a multilateral agency that assists countries with payments difficulties by arranging rescheduling of debts or new credits.

IMMFA Institutional Money Market Funds Association. This is the trade association that represents the European industry in triple-A-rated money market funds.

index fund A fund constructed to track an appropriate stock market index (e.g. the FTSE All-Share Index).

inter-bank market A money market involving lending and borrowing between banks.

investment bank A bank that is involved in the commencement, underwriting and distribution of new issues of securities.

IRP Interest rate parity. This is the requirement that the difference in interest rates between two countries be matched by the forward exchange rate premium/discount.

Islamic bank A bank that conforms to Sharia law as interpreted by Islamic scholars.

ISMA International Securities Markets Association. 
junior bond A bond with a lower claim to income and principal than a senior bond but with a superior claim than equity. Also called a subordinate or mezzanine bond.

junk bond A high-risk, high-return bond. Substantial volumes of junk bonds were issued to finance buy-outs (leveraged buy-outs) in the US during a wave of corporate restructuring in the late 1980s. A junk bond has a credit rating of less than BBB.

LCR Liquidity coverage ratio. This is the ratio of high-quality liquid assets to net cash outflows over the next 30 days. It is a measure of control of a bank's liquidity introduced in the Basel III accord.

LDC Less developed country.

lender of last resort An institution, normally the central bank, that underpins the financial system by lending to banks, or more occasionally domestic financial firms, that are facing a liquidity crisis but are basically sound in the long run.

leverage The proportion of debt in the capital structure. Under the Basel accords it is measured as assets/tier 1 capital.

LIBID London inter-bank bid rate. This is the rate of interest paid on deposits in the London inter-bank market.

LIBOR London inter-bank offered rate. This is the rate at which banks are willing to lend funds in the London inter-bank market.

long position An investor is said to be long if he or she holds a positive net balance in a particular or group of securities or commodities. A long position benefits the investor if prices rise.

LSE London Stock Exchange.

MAD Market Abuse Directive (issued by the European Union). management buy-out The purchase of an existing company by its incumbent management, usually financed by a venture capital fund.

margin Borrowed money employed to finance the buying of assets. This is known as 'buying on margin'. The term 'margin' also refers to the deposit of collateral required in a contract (e.g. on an exchange).

market maker An institution that undertakes to sell and buy a commodity or financial instrument on a continuous basis. This ensures that others can always buy or sell, thus providing liquidity.

matching The practice of securing a distribution of assets that is equal to that of the liabilities in respect of characteristics such as maturity or currency denomination.

maturity The time to the expiry of a loan or debt. Original maturity is the time to expiry when the loan was issued.

merchant bank A bank that makes profits from carrying out services for corporate customers in addition to lending. The types of services include portfolio advice, new issues advice and underwriting, accepting bills of exchange, advising on takeovers and mergers, and foreign currency services. Also known as an investment bank. 
mezzanine bond See 'junior bond'.

MFI Monetary financial institution. This category includes retail and wholesale banks and also building societies.

MFID Markets in Financial Instruments Directive (issued by the EU). Introduced in 2007. MFID II is likely to operate from 2018.

MG Metalgesellschaft.

MGRM Metalgesellschaft Refining and Marketing.

MMD Money market deposit.

MMF Money market fund. This is a mutual fund that invests the proceeds of the fund in short-term money market securities.

MPC Monetary Policy Committee. This is the body with the responsibility of setting UK interest rates.

MREL Minimum requirement of own funds and eligible liabilities. This is set individually for each bank in the European Union based on its total liabilities. The objective of MREL is to ensure that a bank has sufficient liabilities that could be 'bailed in', thus moving the burden of recapitalising a failed bank from the taxpayers to the debt holders.

MTF Multilateral trading facility; a category of institution recognised by MFID.

MTN Medium-term note. This is paper issued with an original maturity of more than one year but less than five years.

mutual fund A fund that pools assets from individual investors and invests them.

narrow bank A bank that is legally restricted to providing retail banking services.

NASDAQ National Association of Securities Dealers Automated Quotations System. This is the computerised price information system used by dealers in the over-the-counter (OTC) market in the US.

NAV Net asset value (per share). This is the value of assets less liabilities divided by the number of issued shares.

NIC Newly industrialising country.

NIF Note-issuance facility. This is a mechanism whereby a bank (or more commonly a syndicate of banks) arranges and guarantees the availability of funds from the issue of a succession of short-term notes (commonly three or six months). In the case of these notes not being taken up by the market, the banks will provide the funds.

note A short-term financial instrument similar to a bond. Unlike a bond, a note is essentially a short-term instrument.

NSFR Net stable funding ratio. This is the ratio of the available amount of stable funding to required amount of stable funding over a year's horizon. It is a measure of control of a bank's liquidity introduced in the Basel III accord.

OECD Organisation for Economic Co-operation and Development. Its members represent the major world economies. 
OEIC Open-ended investment company. This is a type of collective investment fund that came into existence in January 1997. Such companies have a structure like investment trusts but are similar to unit trusts (i.e. are open-ended) in that the number of shares or units can vary from day to day.

off-balance-sheet business A type of business that does not create liabilities or assets for banks (or other businesses). Fees are usually generated, along with contingent liabilities. Examples are NIFs, forward exchange contracts and option writing.

offer price The price at which a market maker (q.v.) is prepared to sell securities.

offshore bank A subsidiary bank, such as a eurobank (q.v.), which operates in a currency other than that of the host country. An alternative definition emphasises business carried out with non-residents in addition to the currency definition.

OFT Office of Fair Trading. This UK body was closed 2014 and its responsibilities were transferred to the Competition and Markets Authority and the Financial Conduct Authority.

ONS Office for National Statistics.

OPEC Organization of the Petroleum Exporting Countries.

option The right but not the obligation to buy (a 'call' option) or sell

(a 'put' option) a commodity or financial instrument in return for the payment of a premium. The seller of an option is called the 'writer'.

OSF Operational standing facility. This is a facility for banks to borrow or make deposits at the Bank of England.

OTC Over-the-counter (market). This is an informal dealer-based market.

OTC option An option that is tailor-made for the purchaser and that cannot be sold.

OTF Organised trading facility; a category of institution recognised by MFID.

Pension Protection Fund A fund set up to take over a failed pension fund and compensate its members.

perpetual FRN A note issued without provision for redemption.

PIL Physical investment (opportunities) line.

plc Public limited company.

PPP Purchasing power parity. This is a theory of exchange rate determination whereby exchange rates represent the relative prices of goods in two countries.

PRA Prudential Regulation Authority. This committee of the Bank of England is responsible for the regulation of banks and insurance companies in the UK.

primary market A market for new issues of securities.

private equity A fund financed by private investors and institutions to make investments directly in private companies or to finance buy-outs. 
put option An option that gives the right to sell the underlying security at an agreed price.

QE Quantitative easing. This is the policy followed by central banks to increase the money supply by purchase of securities.

RATE Risk Assessment, Tools and Evaluation.

real option An option that arises from business investment decisions, for example to build a new factory, if a specific event occurs.

repurchase agreement (repo) An agreement to sell securities and repurchase them at a later date, both prices being agreed at the time of the initial sale. This is in effect an agreement to lend money with collateral and the two prices would reflect this.

retail bank A bank that deals mainly with retail customers. This is the large-volume, low-value end of banking.

reverse repo A repo that is initiated by the buyer of the security rather than the seller (as in a repo).

risk averse An investor is said to be risk averse if he or she will take on more risk only if there is an adequate increase in return.

risk neutral An investor whose motivation depends entirely on the return on an asset, regardless of risk.

RM Regulated market; a category of institution recognised by MFID.

RMBS Residential mortgage backed securities.

rollover credit A loan that is renewed (rolled over) at fixed intervals, with the interest rate being altered in line with a key rate such as LIBOR (q.v.). Also known as revolving credit.

RTGS Real-time gross settlement. This means that all inter-bank transactions are settled in the accounts of the central bank as they occur.

S\&P Standard and Poor's Financial Services. The company operates a credit rating agency.

savings and loans association In the US, an institution that accepts deposits and makes loans, mainly in the form of mortgages. These associations are the equivalent of building societies in the UK.

secondary market A market for the sale and purchase of existing securities, as opposed to a market for the sale (or issue) of new securities, which is termed the primary market (q.v.).

secured bond A bond that is secured either by specific assets of the issuer or by a floating charge against the issuer's assets, so that in the case of bankruptcy the proceeds from the sale of those assets accrue to the bond holders.

Securities and Exchange Commission A US investment regulatory body. securitisation The process by which existing non-negotiable debt (such as bank loans) is changed into a security which is marketable. The term can also be used in a broader sense to indicate the change of procedure through which debt that was formerly obtained by bank lending (i.e. was non-negotiable) is issued in marketable forms such as a NIF. 
SERPS State Earnings-Related Pension Scheme.

SETS Stock Exchange Automatic Trading System.

shadow banking system Institutions providing credit intermediation but outside the regular banking system.

short position An investor is said to be short if he or she holds a negative net balance in a particular or group of securities or commodities. A short position benefits the investor if prices fall.

short selling Selling in the market an asset that the dealer does not own, in the hope the price will fall.

SIB Securities and Investment Board.

SIP Statement of investment principles.

Solvency II An EU directive providing for the harmonisation of regulations governing life assurance operations across the EU. It was due to be fully implemented by 2016 .

sovereign fund A pool of investment funds under the control of the state. spot rate The rate (most commonly exchange) at which transactions completed now rather than at some future time. In the case of foreign exchange transactions, settlement must be completed within two days. spread The gap between an institution's buying and selling rates for financial securities and foreign exchange. It can also refer to the margin above the base rate, such as LIBOR (q.v.), at which a specific loan is priced.

SPV Special-purpose vehicle.

statutory funding objective The requirement that a pension fund has sufficient assets to cover its liabilities.

straddle An option trading strategy that involves the simultaneous purchase (sale) of both call and put options at the same strike price.

strangle An option trading strategy that involves the simultaneous purchase (sale) of both call and put options at different strike prices.

strap An option trading strategy that involves the simultaneous purchase (sale) of two call and one put options at the same strike price.

stress test A test carried out by the regulatory authorities to check how vulnerable banks are to exogenous shocks. The test involves altering the value of an exogenous variable and examining the effects on the bank's balance sheet.

strip An option trading strategy that involves the simultaneous purchase (sale) of one call and two put options at the same strike price.

stripping The process of separating a conventional coupon-bearing bond into its constituent interest and principal payments.

subordinated debt Debt that ranks after all other debt for repayment in the event of liquidation. See also 'Junior bond'.

SURF Step-up recovery FRN (q.v.).

swap An exchange of currencies or of debt with different characteristics such as interest rate type. 
syndicated loan A loan made by a group of banks. Normally one bank (or sometimes more than one) acts as the lead bank and arranges to sell all or some of the debt to other banks, which are termed participating banks. term structure The variation in interest rates according to the maturity of the debt.

tick The minimum possible price change in a security.

TLAC Total loss-absorbing capacity. This refers to the quantity of liabilities held that can legally be written down or converted into equity in the case of resolution of the bank.

traded option An option in the form of a standardised agreement that the purchaser can sell on an organised market.

UCITS Undertaking for collective investment in transferrable securities (authorised under EU legislation).

underwriting A process whereby financial institutions guarantee that a debt or equity issue will be taken up at a specified price. In the event of the market not purchasing all of the issue, the institutions will purchase the balance.

universal bank An institution that carries out a wide range of banking services, both retail and wholesale.

value at risk (VaR) An analysis system used to determine how much could be lost on a portfolio in a given time period.

vertical spread An option trading strategy involving the simultaneous purchase and sale of options with different exercise prices.

volatility The movement of the price of a security within a given time period.

wholesale bank A bank that operates a wide range of services outside the traditional role of banking (i.e. accepting deposits and making loans). Also known as an investment bank.

withholding tax A tax that is deducted at source prior to payment of interest on dividends.

yield curve A graphical representation of the term structure of interest rates.

yield to maturity The return on a security that is held to maturity. 